\title{
Reuna
}

\section{NURSING LEADERSHIP AS A COMPETITIVE ADVANTAGE IN HOSPITALS CONSOLIDATION}

\section{A LIDERANÇA DE ENFERMAGEM COMO VANTAGEM COMPETITIVA NA CONSOLIDAÇÃO DE HOSPITAIS}

\author{
http://dx.doi.org/10.21714/2179-8834/2020v25n2p20-32
}

\author{
Sérgio Almeida Migowski \\ Instituto Federal do Rio Grande do Sul (IFRS), Brasil. \\ E-mail: sergiomigowski@gmail.com \\ Cláudia de Souza Libânio \\ Universidade Federal de Ciências da Saúde de Porto Alegre (UFCSPA), Brasil. \\ E-mail: clasl@terra.com.br \\ Eliana Rustick Migowski \\ Santa Casa de Misericórdia de Porto Alegre, Brasil. \\ E-mail: elianamigowski@gmail.com \\ Francisco Dias Duarte \\ Universidade do Vale do Rio dos Sinos (UNISINOS), Brasil. \\ E-mail: francisco.duarte@grupofleury.com.br
}

Submissão: 2 Jan. 2020. Publicação: 30 Jun. 2020. Sistema de avaliação: Double blind review.

Centro Universitário UNA, Belo Horizonte - MG, Brasil. Editor geral: Prof. Dr. Thiago Soares Nunes

Este artigo encontra-se disponível nos seguintes endereços eletrônicos:

http://revistas.una.br/index.php/reuna/article/view/1107

http://dx.doi.org/10.21714/2179-8834/2020v25n2p20-32

\begin{abstract}
This theoretical essay aims to propose a framework that enables to maintain the gains in hospitals involved with merger and acquisition processes by including the nursing leaderships. It implies a new perspective on the Structure, Conduct, Performance (SCP) model. If companies intend to grow with an adequate quality and sustainability standard, they must reverse the SCP model to CSP, in which managerial conduct, through nursing leadership, is the driver of the entire process, reflecting in the market structure and, consequently, in the performance. As methodological procedures, classical and contemporary academic studies on efficiency losses in merger and acquisition processes and nursing management have been critically reviewed and applied to support the argument in order to propose a framework.
\end{abstract}

Keywords: Hospital; Merger and acquisition; Nursing leadership.

\section{Resumo}

Este ensaio teórico objetiva propor um framework que possibilite a manutenção de ganhos em hospitais inseridos em processos de fusão e aquisição através da inclusão das lideranças de enfermagem. Isso implica em uma nova perspectiva sobre o modelo 
Estrutura, Conduta, Desempenho (ECD). Se as organizações desejam crescer com adequados padrões de qualidade e sustentabilidade, elas devem inverter o modelo para CED, no qual a conduta gerencial, através das lideranças de enfermagem, é a fonte de todo o processo, refletindo-se na estrutura de mercado e, consequentemente, no desempenho. Como procedimento metodológico, estudos acadêmicos clássicos e contemporâneos sobre perdas de eficiência em processos de fusão e aquisição e lideranças de enfermagem foram revisados criticamente e para apoiar o argumento.

Palavras-chave: Hospital; Fusão e aquisição; Liderança de enfermagem.

\section{Introduction}

Hospital organizations are singular in one point: on one hand, the management is highly pressured to control costs; on the other, it is forced to offer specialized and highly qualified services (ARONSSON et al., 2011). In order to avoid this tradeoff, since the quality management in this sector is directly related to the service outcome, organizations have opted for merging and acquisition processes as a way to obtain scale gains. This has occurred both in Brazil and Europe, USA, and Canada (PÁDUA FILHO, 2014; WEIL, 2010).

This reduction in the number of actors, however, can generate undesirable effects to the society. When organizations expand their capacity and economies of scale, there is the tendency that smaller, inefficient firms do not manage the need that larger companies do their price reductions. The concentration of organizations reaches such a level that the dispute is reduced, thus reflecting in the competitive conduct, which leads to market failures $(\mathrm{BLOCH}, 2000)$. In the North-American hospital sector, for example, there was a reduction of $18 \%$ in the number of hospitals and $31 \%$ in the number of hospital beds since 2006 (COSTELLO et al., 2011). In 1990, 44\% of American hospitals were part of a group of hospitals. In 2013, this number was already at $70 \%$ (BURIK; DIXON, 2013).

While the market does not reach a balance point that is interesting for all those involved, fewer options are offered, the prices of hospital services are increased, and the competing environment is reduced (PORTER; LEE, 2013). If, on the one hand, it cannot be said that there is no competition due to future incomings (POSSAS, 2006), the fact is that the entry barriers are so numerous (path dependency, investment capital, access to technology, human resources, economies of scale, economies of scope, etc.) that end up hindering the emergence of new actors (PORTER; TEISBERG, 2007).

The market structure was addressed by Scherer and Ross (1990) as playing a significant role in the way the firms design their conduct, which may be reflected in their performance. Although the Structure, Conduct, Performance (SCP) model has received much criticism, its premise of concentration (reduction in the number of competitors) for economies of scale has been a common practice in the hospital sector.

On the others, despite the efforts, the concentration in the hospital sector has not necessarily generated gains in efficiency or in achieving a satisfactory financial and qualitative performance. Recent studies point that mergers and acquisitions may not result in enhancing technical efficiency (HAYFORD, 2012; MUTTER et al., 2011; COOPER et al., 2010) and their excessive dimension may actually generate 
diseconomies of scale (CONDEIXA, 2012) or a notable decline in cost savings after one year (HARRISON, 2010).

Such difficulties in obtaining gains may be related to the way hospital managers view nursing professionals. Despite the several studies relating the impact of the services provided by nursing (GIRVIN et al., 2016; ALLNUTT et al., 2010), it has been treated only as a cost center, said to be responsible for $25 \%$ of the total operational costs (MAENHOUT; VANHOUCKE, 2013) and 44\% of the direct costs (WELTON et al., 2006) in a hospital. This view does not consider the degree of attention given, leading to a lack of economic visibility (LASATER, 2013; DUFFIELD et al., 2007).

Given this scenario, this study aims to propose a framework that enables to maintain the gains in hospitals involved with merger and acquisition processes by including the nursing leaderships. It implies a new perspective on the SCP model. If companies intend to grow with an adequate quality and sustainability standard, they must reverse the SCP model to CSP, in which managerial conduct, through nursing leadership, is the driver of the entire process, reflecting in the market structure and, consequently, in the performance.

A study carried out by Idel et al. (2003) showed that, after the merger was announced, there was a significant increase in emotional stress, especially in the performance of nursing professionals. Bernstrøm and Kjekshus (2015) identified a significant increase of these professionals taking work leaves, when they work in an environment with significant changes in the organizational structure. Fagerström and Salmelas (2010) stressed the importance of permanent dialogue with their direct leadership to reduce conflicts and uncertainties in hospitals through merger processes.

It is, therefore, about improving the managerial capacity or conduct through the nursing leadership as a means to achieve real benefits for the hospitals, given the need for concentration, without triple losses to society (increasing prices, fewer options, and reducing efficiency). As methodological procedures, classical and contemporary academic studies on efficiency losses in merger and acquisition processes and nursing management have been critically reviewed and applied to support the argument in order to propose a framework.

The present article is structured into five sections. Starting with this first introductory section, the second section presents the influence of price concentration, efficiency, and size of the hospitals. The following sections address the SCP Model, the nursing leadership, and the development of a framework that makes it possible for hospital managers to realize that, as it involves the nursing leaderships, the conduct of each of the companies of a conglomerate determines the conglomerate's conduct and, consequently, the market structure. Then, Final Considerations are presented.

\section{Theoretical Discussion}

\subsection{The influence of the concentration of prices, efficiency, and size}

The rising prices resulting from the merger were found by Haas-Wilson and Garmon (2011) and Dafny (2014), because it reduces the bargaining power and customer options (KURAMOTO, 2014). Brown Jr. et al. (2012) explain that the rising prices are also due to the pressure of health insurance companies to push harder for quality certifications, which would mean an expansion of investment. Kellis and 
Rumberger (2010) and Chen and Chuang (2013) argue that the high prices charged by physicians and North-American hospitals are due to the little competition in the sector, as a result of the concentration of large conglomerates.

Several authors have addressed the need of managing beds as their number has been reduced, while the demand is increasing (BAZZOLI et al., 2006; BURNS et al., 2008; KUSSEROW, 2013). The studies started to propose ways to improve the scheduled capacity, through surgical scales avoiding concomitant surgeries of patients in long-term hospitalizations (KOBIS; KENNEDY, 2006; RECHEL et al., 2010).

Regarding the economy of scale, Weil (2010) stresses that it is only perceived in a more substantial way when one of the acquired structures is eliminated. Harrison (2010), in turn, notes that the economy only occurs in the months after the merger operation, but there is a tendency in its decline, as time goes on.

When it comes to the services offered, Ferrier et al. (2013) indicate that the context where the hospital is inserted directly affects its size and performance and this includes the variety of offered specialties. Hospitals located in Los Angeles, for example, have to offer more service options than similar hospitals in Philadelphia. The reason would be directly linked to the customers having to search for solutions for their pathologies. Basically, the more they are far from each other, the more specialties the hospital has to offer.

Kessler and McClellan (2000) found a direct relationship with the increased mortality in concentrated markets, assigning this to the reduction of competition. For Hayford (2012), there was a 3.9\% increase in mortality rates in the hospitals located in markets with greater competition, while for Kessler and McClellan (2000) this difference is $4.4 \%$.

In a context that presents a trend of shrinking and reducing the options for the customers, thus creating an imbalance between offers and demands, there seems to be no agreement in the efficiency profits, despite the reduction in the number of actors. Therefore, the next section presents an overview of the SCP model of Scherer and Ross (1990).

\subsection{The SCP model}

In the SCP (Structure, Conduct, Performance) model, a basis of the study of Scherer and Ross (1990), performance is influenced by the conducts of the sellers and purchasers and would be represented by factors, such as allocational efficiency and technical progress. Allocational efficiency occurs when goods and services are produced (in quality and quantity) as desired by the customers, which is reflected in their exact proportion and price they are willing to pay for them. Thus, it reduces the chance of prices and/or services produced not being of interest to the consumer (CESCONETTO et al., 2008). Conduct, or behavior, in turn, depends on the determination of the price, the product and propaganda strategy, the investments in facilities, the legal techniques, and the research and development, resulting from the structure.

Finally, the structure of a market would be influenced by the number of purchasers and sellers, differentiation of products, barriers to the entry, cost structures, vertical integration, and diversification. The result of the concentration would be the 
increase in market power and, consequently, the increase in the prices charged (SCHERER; ROSS, 1990).

On the other hand, even with fewer competitors, the increase in bargaining power, economies of scale, and the improvement of learning for a greater number of similar surgeries, the consolidation processes result, in some cases, in the increase in mortality rates (HAYFORD, 2012; KESSLER; McCLELLAN, 2000), diseconomies of scale (CONDEIXA, 2012; KRISTENSEN et al., 2010), and, consequently, in smaller allocational efficiency. This suggests that the structure does not determine the conduct, as it is reflected in the performance. If the organizations wish to grow, it seems necessary to reverse the SCP model to C-S-P, which requires better managerial conducts on the part of each of the actors involved, otherwise, they would perpetuate the managerial failures committed before the consolidations. Such conducts go through more efficient management of internal resources and should be replicated by all components of the conglomerate, which is reflected, in the end, in the very structure of the market. This concept of management requires the involvement of nursing leaderships.

\subsection{Nursing Leadership}

In the hospitals, leadership has a significant role in restoring the health conditions of the patients since the care highly depends on the coordination of the contribution from several experts (WHEELER; STOLLER, 2011). It has the difficult task of managing the different expectations, increasing their satisfaction and commitment and reducing turnover (CENNAMO; GARDNER, 2008), in addition to solving the conflicts between generations and distinct cultures (CURRIE; HARVEY, 2000).

Such managerial challenges cannot be left out because the various professionals who are part of it its most important resource, as the organizations' sustainability results from their satisfaction and commitment in carrying out the several activities (MOSADEGHRAD; FERDOSI, 2013). It is not coincidental that some studies associate the individual commitment with cost reduction, customer satisfaction, error reduction (CHAKRABORTY; KAYNAK, 2016; GOWEN III et al., 2006), while others associate the existence of a leadership considered as reliable that supports the other professionals of the team by reducing falls of patients, pressure ulcers, and associated infections (WONG, 2015; BLEGEN et al., 2011).

Moreover, patient safety (which results from the combination of people and processes and both depend on the leadership) must be the stimulus for the creation of a safe environment (JARRETT, 2017). As the processes in a hospital organization are conducted by several professionals (OSMO, 2012) which are connected to different sectors and which should jointly seek greater efficiency in processes and an improvement in quality management. This implies a change in managerial conduct.

\subsection{Changing the S-C-P model to C-S-P}

According to the presented studies, the involvement of the nursing leaderships is related to organizational performance, making it possible for a bigger qualification of the services offered. Therefore, this study considers changing the SCP Model (SCHERER; ROSS, 1990), placing the conduct as the factor that will impact the market 
structure, which is reflected in the performance of the hospital company and in the profits for the society.

This framework proposes to (Figure 1) mitigate the possibility that the need for economies of scale to make investments in technology does not generate the expected impact on the firm's performance and benefits desired by society. Unlike other segments, the hospital service needs to be consumed at the time of need and, preferably, in a place close to the user, since the time factor can be decisive for the patient's recovery (FERRIER et al., 2013). In addition, the knowledge of the professionals involved is extremely relevant to the efficiency of the processes (MOSADEGHRAD; FERDOSI, 2013).

Figure 1 - Theoretical Framework CSP-RBV based on the SCP Model (SCHERER; ROSS, 1990).

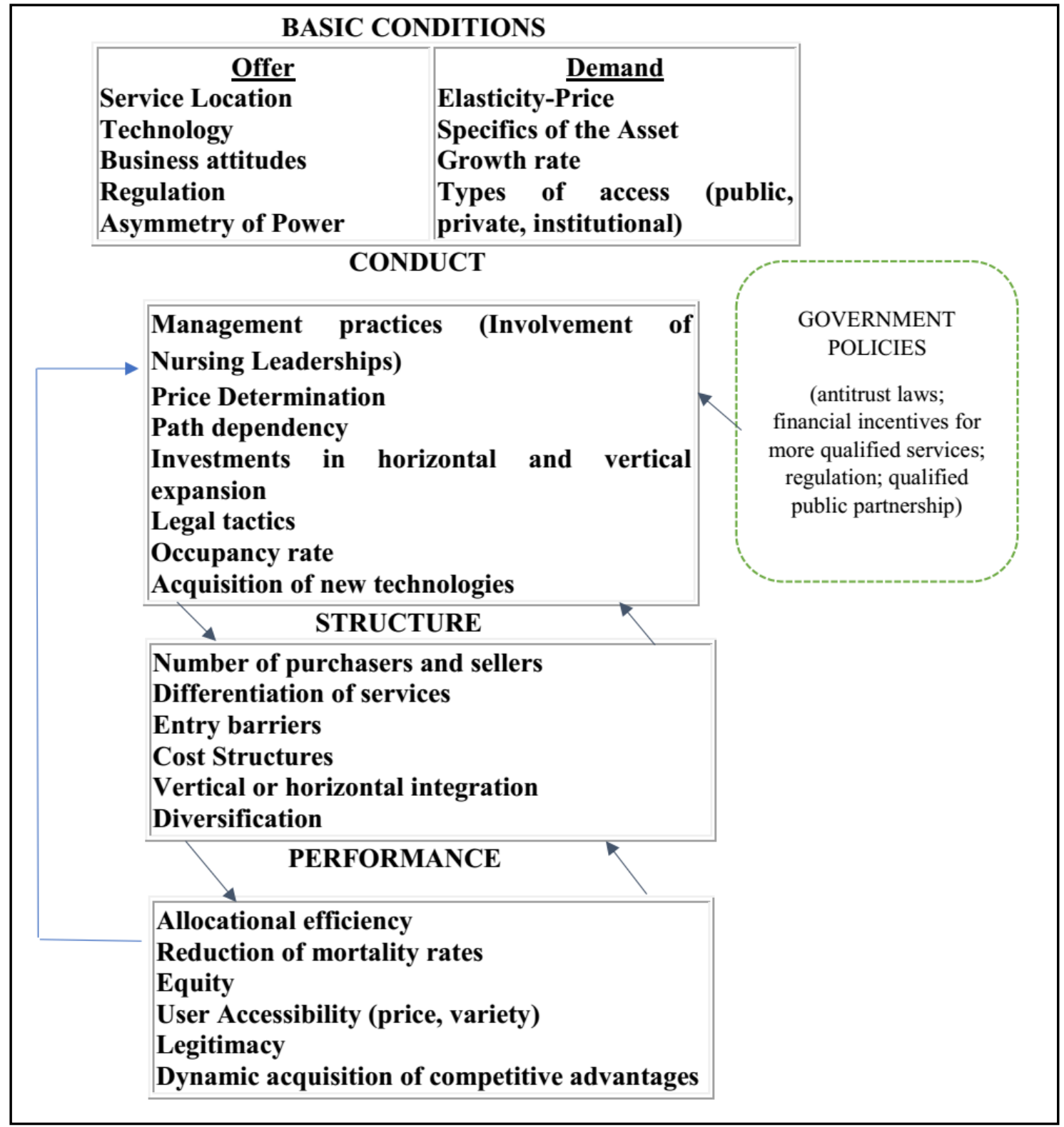

Source: the authors. 
Considering that the constituent firms of the hospital sector, regardless of their geographical location, are subject to the same regulations, the performance varies greatly among them. Even if they have experienced a greater bargaining power when they focus on a single company and a demand higher than the offer to the extent that some of them continue growing financially and qualitatively, others show a decrease in both aspects, although they are subject to the same environmental conditions (CONDEIXA, 2012; HARRISON, 2010).

From this perspective, the managerial practices and, among them, the nursing leaderships (conduct) seem to be the main source of performance heterogeneity in the organizations. This occurs because all understand the importance of the activities of each one and are committed to an optimum result (MORELLO et al., 2013). With the correct use of the leadership, the ones being led understand how important it is to perform the task requested as well as to perform it in the best way possible (BISEL et al., 2012).

In this particular segment, any action concerning the management of the care staff management impacts the entire system as only the nursing staff represents typically $60 \%$ of the total personnel of a hospital (FEDERAÇÃO..., 2014). Therefore, the qualification in the administrative management of these professionals makes it possible to improve the systemic view by understanding that their actions can impact the entire company (DE OLIVEIRA et al., 2014). The adequate management of the existing material resources in the sector implies, for example, reduction of the available materials, only requested when they are effectively necessary, which can reduce the small supplies, common in the diverse units of a hospital (BUGS et al., 2017), which is reflected in the working capital.

The insertion of all the materials used in the patient's records has consequences not only in the management of supplies, but also in the invoicing, since it is responsible for the materials and medicines of health insurance to be charged. This action ends up reducing audit costs that do not add value to the hospital because they must try to raise by sampling the number of items to charge, which were not described in the patient records during the administration (VIANA et al., 2016). The training of nurses also allows for a humanized management of the team, which contributes to reducing the number of leaves and turnover - unwanted factors when the quality improvement is aimed (VALENÇA et al., 2016).

As these teams are involved both in the hospitalization and discharge of patients, their best practices can reduce the patients' stay, thus allowing for the physical facilities and equipment to be improved (GRAY, 2016). This action alone, for example, can postpone plans of investment in enhancing the structure, which tends to raise the expenditure of the operations (more structure, more personnel).

The conducts that can be adopted to reach such objective are: (i) change of timetables for the examinations, so that the results are already at the time of the visit of the attending physicians, which is reflected in the early discharge of the bed; (ii) after the discharge process, immediate communication to the teams responsible for the maintenance and cleaning, so that the room is available for a new hospitalization, which is often from the emergency service of the same institution (GRAY, 2016); (iii) a team dedicated to leading the patients to the surgery room and to imaging tests at the stipulated time, enabling an optimal use of those structures and avoiding the REUNA, Belo Horizonte - MG, Brasil, v. 25, п. 2, p. 20-32, Abr. - Jun. 2020 - ISSN 2179-8834 
professionals to take leaves; (iii) the correct discharge of medicines and food for the patients with surgery, thus preventing it from being canceled. A surgery room that is not used, following a schedule, creates immediate damage, as another surgery cannot be scheduled without planning, which suggests that it is necessary a multidisciplinary involvement in order to prevent such losses (HOVLID; BUKVE, 2014).

This set of actions is reflected in allocational efficiency. It could prevent the investments in technology to not being carried out (cost of investment opportunity). The result of the allocational efficiency, the improvement of care indicators because of the implementation of the best practices, and greater accessibility on the part of the consumer to the system can result in a greater legitimacy of this hospital towards society. The legitimacy, in addition to increasing the bargaining power in the negotiations, could be perceived both as a competitive advantage and an entry barrier, since new competitors will demand more time to be recognized (CESCONETTO et al., 2008).

As a reflection of the conduct adopted, the market structure ends up having the number of sellers suitable to the demand and offering the necessary services to the context where it is inserted. Once more, the path dependence works as an important barrier of entry and makes it possible for superior financial performance to occur since the administrative management becomes a task of several individuals. If a competitor wishes to hire some of these professionals, there is no guarantee that they will be able to replicate other organizational characteristics that make their performance possible. All these factors are sources of competitive advantage (BARNEY; HESTERLY, 2007).

\section{Final Considerations}

There are several reasons for the concentration, with the main one being the search for efficiency while maintaining the sustainability of the organizations involved. Nevertheless, these strategies of consolidation in the sector do not appear to guarantee a better service to society or of sustainability for the companies involved. The adoption of new management practices, with the effective involvement of the nursing leaderships in the merger and acquisition processes, can assist in obtaining profits that will be reflected in the market structure and the performance of the hospitals.

By recognizing the actual cost structure and the desired quality, with the support of the nursing leaderships, there will be more room to negotiate with health insurance plans and insurance companies, which in turn will recognize that they are not paying higher values due to the inefficiencies in the process. Given the increased legitimacy in light of the improvement in the efficiency indicators, range of services suited to the context, optimization in the use of all resources involved, and the recognition by society that the price charged is fair, the market structure will be changed by new alliances, merger, acquisition, or expansion, only when there is a real need on the part of the demand.

It is expected that the proposed framework could serve to aid hospital managers to check the necessary importance to nursing leaderships, avoiding that the gains made during the concentration are not lost because of the negative impacts that may be caused in each of the assistance professionals belonging to the hospitals that are undergoing processes of merger or acquisition. 


\section{Referências}

ALLNUTT, J.; ALLNUTT, N.; MCMASTER, R.; O'CONNELL, J.; MIDDLETON, S.; HILLEGE, S.; DELLA P.R.; GARDNER, G.E.; GARDNER, A. Clients' understanding of the role of nurse practitioners. Australian Health Review, v. 34, n. 1, p. 59-65, 2010.

ARONSSON, H.; ABRAHAMSSON, M.; SPENS, K. Developing lean and agile health care supply chains. Supply Chain Management: An International Journal, v. 16, n. 3, p. 176-183, 2011.

BARNEY, J.; HESTERLY, W. S. Administração estratégica e vantagem competitiva. São Paulo: Pearson Prentice Hall, 2007.

BAZZOLI, G.J.; BREWSTER, L.R.; MAY, J.H.; KUO, S. The Transition from Excess Capacity to Strained Capacity in U.S. Hospitals. Mitbank Quarterly, v. 84, n. 2, p. 273304, 2006.

BERNSTRØM, V. H.; KJEKSHUS, L.E. Effect of organisational change type and frequency on long-term sickness absence in hospitals. Journal of Nursing Management, v. 23, n. 6, p. 813-822, 2015.

BISEL, R. S.; MESSERSMITH, A. S.; KELLEY, K. M. Supervisor-Subordinate Communication: Hierarchical Mum Effect Meets Organizational Learning. Journal of Business Communication, v. 49, n. 2, p. 128-147, 2012.

BLEGEN, M. A.; GOODE, C. J.; SPETZ, J.; VAUGHN, T.; PARK, S. H. Nurse staffing effects on patient outcomes: safety-net and non-safety-net hospitals. Medical Care, v. 49, n. 4, p. 406-414, 2011.

$\mathrm{BLOCH}, \mathrm{H}$. Schumpeter and Steindl on the dynamics of competition. Journal of Evolutionary Economics, v. 10, n. 3, p. 343-353, 2000.

BROWN JR., T. C.; WERLING, K. A.; WALKER, B. C.; BURGDORFER, R. J.; SHIELDS, J. J. Current trends in hospital mergers and acquisitions. Healthcare Financial Management, v. 66, p. 114-118, 2012.

BUGS, T. V.; RIGO, D. D. F. H.; BOHRER, C. D.; BORGES, F.; DE OLIVEIRA, J. L. C.; TONINI, N. S. Dificuldades do enfermeiro no gerenciamento da unidade de prontosocorro hospitalar. Revista de Enfermagem da Universidade Federal de Santa Maria, v. 7, n. 1, p. 90-99, 2017.

BURIK, D.; DIXON, T. What's Really Happening with US Health Systems Consolidation. Navigant Pulse, Issue III, p. 4, 2013.

BURNS, D. J.; CHINTA, R.; KASHYAP, V.; MANOLIS, C.; SEN, A. Hospital Care and Capacity in the Tri-State Region of Indiana, Kentucky and Ohio: analysis and insights. Health Marketing Quarterly, v. 25, n. 3, p. 254-269, 2008.

CENNAMO, L.; GARDNER, D. Generational differences in work values, outcomes and person-organisation values fit. Journal of Managerial Psychology, v. 23, n. 8, p. 891906, 2008. 
CESCONETTO, A.; DOS SANTOS, L. J.; CALVO, M. C. M. Avaliação da eficiência produtiva de hospitais do SUS de Santa Catarina. Cadernos de Saúde Pública, v. 24, n. 10, p. 2407-2417, 2008.

CHAKRABORTY, S.; KAYNAK, H. Linking hospital leadership, healthcare team effectiveness and patient care quality. In: Academy of Management Proceedings, v. 2016, n. 1, p. 11165. Academy of Management, 2016.

CHEN, K. C.; CHUANG, K. C. Using systems thinking to analyse healthcare in the United States: should we move to a government sponsored healthcare system? Academy of Healthcare Management, v. 9, n. 2, p. 3-12, 2013.

CONDEIXA, I. S. Do hospital mergers improve the performance of hospital efficiency? 2012. 52f. Dissertation (Master's degree in Economy). Universidade de Aveiro, Aveiro, Portugal, 2012.

COOPER, Z.; GIBBONS, S.; JONES, S.; McGUIRE, A. Does hospital competition improve efficiency? An analysis of the recent market-based reforms to the English NHS. CEP discussion papers, No. 988. Centre for Economic Performance, London School of Economics and Political Science, London, UK, 2010.

COSTELLO, M. M.; WEST JR., D. J.; RAMIREZ, B. Hospitals for Sale. Hospital Topics, v. 89, n. 3, p. 69-73, 2011.

CURRIE, V. L.; HARVEY, G. The use of care pathways as tools to support the implementation of evidence-based practice. Journal of Interprofessional Care, v. 14, n. 4, p. 311-324, 2000.

DAFNY, L. Hospital Industry Consolidation: still more to come? New England Journal of Medicine, v. 370, n. 3, p. 198-199, 2014.

DE OLIVEIRA, W. T.; HADDAD, M. D. C. L.; VANNUCHI, M. T. O.; RODRIGUES, A. V. D.; PISSINATI, P. D. S. C. Capacitação de enfermeiros de um Hospital Universitário público na gestão de custo. Revista de Enfermagem da Universidade Federal de Santa Maria, v. 4, n. 3, p. 566-574, 2014.

DUFFIELD, C.; KEARIN, M.; LEONARD, J. The Impact of Hospital Structure and Restructuring on the Nursing Workforce. Australian Journal of Advanced Nursing, v. 24, n. 4, p. 42-46, 2007.

FAGERSTRÖM, M. L.; SALMELAS, S. Leading change: a challenge for leaders in Nordic health care. Journal of Nursing Management, v. 18, n. 5, p. 613-617, 2010.

FEDERAÇÃO DAS SANTAS CASAS E HOSPITAIS BENEFICENTES, RELIGIOSOS E FILANTRÓPICOS DO RIO GRANDE DO SUL. [Site]. 2014. Retrieved from <http://www.hospfilrs.org.br/index-7.html>. Accessed 01 Jan. 2020.

FERRIER, G. D.; LELEU, H.; MOISES, J.; VALDMANIS, V. G. The Focus Efficiency of U.S. Hospitals. Atlantic Economic Journal, v. 41, n. 3, p. 241-263, 2013. 
GIRVIN, J.; JACKSON, D.; HUTCHINSON, M. Contemporary public perceptions of nursing: a systematic review and narrative synthesis of the international research evidence. Journal of Nursing Management, v. 24, n. 8, p. 994-1006, 2016.

GOWEN III, C. R.; McFADDEN, K. L.; HOOBLER, J. M.; TALLON, W. J. Exploring the efficacy of healthcare quality practices, employee commitment, and employee control. Journal of Operations Management, v. 24, n. 6, p. 765-778, 2006.

GRAY, E. A. Discharge by 11:00 a.m.: The Significance of Discharge Planning. MEDSURG Nursing, v. 25, p. 381-384, 2016.

HAAS-WILSON, D.; GARMON, C. Hospital Mergers and Competitive Effects: two retrospective analyses. International Journal of the Economics of Business, v. 18, n. 1, p. 17-32, 2011.

HARRISON, T. D. Do Mergers Really Reduce Costs? Evidence from Hospitals. Economic Inquiry, n. 4, p. 1054-1069, 2010.

HAYFORD, T. B. The Impact of Hospital Mergers on Treatment Intensity and Health Outcomes. Health Services Research, v. 47, n. 3 pt. 1, p. 1008-1022, 2012.

HOVLID, E.; BUKVE, O. A qualitative study of contextual factors' impact on measures to reduce surgery cancellations. BMC Health Services Research, v. 14, p. 1-21, 2014.

IDEL, M.; MELAMED, S.; MERLOB, P.; YAHAV, J.; HENDEL, T.; KAPLAN, B. Influence of a merger on nurses' emotional well-being: the importance of self-efficacy and emotional reactivity. Journal of Nursing Management, v. 11, n. 1, p. 59-63, 2003.

JARRETT, M. P. Patient safety and leadership: Do you walk the walk? Journal of Healthcare Management, v. 62, n. 2, p. 88-92, 2017.

KELLIS, D. S.; RUMBERGER, J. S. Healthcare reform and the hospital industry: what can we expect? Journal of Healthcare Management, v. 55, n. 4, p. 283-296, 2010.

KESSLER, D.; McCLELLAN, M. Is hospital competition socially wasteful? Quarterly Journal of Economics, v. 115, n. 2, p. 577-615, 2000.

KOBIS D. A.; KENNEDY K. M. Healthcare Financial Management. Journal of the Healthcare Financial Management Association, v. 60, n. 10, p. 88-92, 2006.

KRISTENSEN, T.; BOGETOFT, P.; PEDERSEN, K.M. Potential gains from hospital mergers in Denmark. Health Care Management Science, v. 13, p. 334-345, 2010.

KURAMOTO, R.K. Specialties: missing in our healthcare reform strategies? Journal of Healthcare Management, v. 59, n. 2, p. 89-94, 2014.

KUSSEROW, R. P. Mergers and Acquisitions Due Diligence in HealthCare. Journal of Healthcare Compliance, v. 15, p. 61-65, 2013.

LASATER, K.B. Invisible economics of nursing: analysis of a hospital bill through a Foucauldian perspective. Nursing Philosophy, v. 15, n. 3, p. 221-224, 2013. 
MAENHOUT, B.; VANHOUCKE, M. Analyzing the Nursing Organizational Structure and Process from a Scheduling Perspective. Health Care Management Science, v. 16, n. 3, p. 177-196, 2013.

MORELLO, R. T.; LOWTHIAN, J. A.; BARKER, A. L.; McGINNES, R.; DUNT, D.; BRAND, C. Strategies for improving patient safety culture in hospitals: a systematic review. BMJ Quality \& Safety, v. 22, p. 11-18, 2013.

MOSADEGHRAD, A.M.; FERDOSI, M. Leadership, job satisfaction and organizational commitment in healthcare sector: Proposing and testing a model. Materia sociomedica, v. 25, n. 2, p. 121, 2013.

MUTTER, R. L.; ROMANO, P. S.; WONG, H. S. The Effects of US Hospital Consolidations on Hospital Quality. International Journal of the Economics of Business, v. 18, n. 1, p. 90-126, 2011.

OSMO, A. A. Processo Gerencial. In: GONZALO, V. N.; MALIK, A. M. (Eds.). Gestão em Saúde. Rio de Janeiro: Guanabara Koogan, 2012.

PÁDUA FILHO, W. Mergers and Acquisition in Hospital Sector: A Strategic Analysis of the Brazilian Market. International Management Review, v. 10, n. 2, p. 5, 2014.

PORTER, M.; LEE, T. H. The Strategy That Will Fix Health Care. Harvard Business Review, v. 91, n. 10, p. 50-70, 2013.

PORTER, M.; TEISBERG, E. Repensando a Saúde: estratégias para melhorar a qualidade e reduzir os custos. Porto Alegre: Bookman, 2007.

POSSAS, M. S. Concorrência e Inovação. In: PELAEZ, V.; SZMRECSÁNYI, T. (Orgs.). Economia da Inovação Tecnológica. São Paulo: Hucitec, 2006.

RECHEL, B.; WRIGHT, S.; BARLOW, J.; MCKEE, M. Hospital Capacity Planning: from measuring stocks to modelling flows. Bulletin of the World Health Organization, v. 88 , p. 632-636, 2010.

SCHERER, F. M.; ROSS, D. Industrial Market Structure and Economic Performance. Boston: Houghton Mifflin Company, 1990.

VALENÇA, C. N.; DA SILVA, A. F. C.; MARINHO, C.; DA SILVA, M. P.; DE SOUSA, Y. G.; DE MEDEIROS, S. M. Vivências dos profissionais da enfermagem sobre procedimentos executados no hospital. Revista Cubana de Enfermería, v. 32, p. 110, 2016.

VIANA, C. D.; BRAGAS, L. Z. T. D.; LAZZARI, D. D.; GARCIA, C. T. F.; MOURA, G. M. S. S. D. Implantação da auditoria concorrente de enfermagem: um relato de experiência. Texto \& Contexto Enfermagem, v. 25, n. 1, p. e3250014, 2016.

WEIL, T. Hospital Mergers: a panacea? Journal of Health Services Research \& Policy, v. 15, n. 4, p. 251-253, 2010. 
WELTON, J.M.; FISCHER, M.H.; DE GRACE, S.; ZONE-SMITH, L. Hospital Nursing Costs, Billing, and Reimbursement. Nursing Economic, v. 24, n. 5, p. 239-245, 2006.

WHEELER, D.; STOLLER, J. K. Teamwork, teambuilding and leadership in respiratory and health care. Canadian Journal of Respiratory Therapy, v. 47, n. 1, p. 6-11, 2011.

WONG, C. A. Connecting nursing leadership and patient outcomes: state of the science. Journal of Nursing Management, v. 23, n. 3, p. 275-278, 2015. 